\title{
Fostering Culturally Relevant/Responsive Pedagogy and Global Awareness through the Integration of International Service-learning in Courses
}

\author{
Tata Mbugua
}

Abstract: Educators are being asked to respond to the forces of globalization and human interconnectedness that characterize the $21^{\text {st }}$ century. These forces are resulting in changing population demographics and increased migration which is bringing a new complexity to cultural and ethnic diversity within regions, local communities and ultimately in elementary school classrooms. As a response, institutions of higher learning are seeking ways of preparing pre-service teachers who are culturally sensitive and globally aware and who will in turn prepare young children to be world citizens. One way of achieving this goal is to integrate an experiential service-learning component in courses as a way of expanding pre-service teachers perspectives to the world while enhancing their cultural competence, understanding of others different from themselves, commitment to social justice issues, and mastery of course content. This manuscript describes the development of a graduate course at a university in northeast USA, and the subsequent implementation of the course in Kenya with an integrated international service-learning component. Ideas of scholars on multicultural education, global education, culturally relevant pedagogy and service-learning will be used as a way of framing the discussion topic. The positive rewards and some challenges of this course will be discussed along with some concluding remarks.

Key words: Culturally relevant/responsive pedagogy, service-learning, cultural competence, cultural sensitivity, culturally responsive teaching.

The global village of the $21^{\text {st }}$ century has ushered new opportunities and challenges for educators at all levels of the educational enterprise. Specifically, the changing demographics and increased immigration has resulted in 
an ethnically, culturally and linguistically diverse K-12 (kindergarten twelfth grade) student population in the United States of America. As a consequence, the teaching culture in United States is facing two major challenges. The first challenge is a predominantly white, middle to upper class, female, monolingual teaching force interacting with an increasingly diverse student population [Darling-Hammond, 2000; Mbugua, 2004; Spring, 2004]. The second challenge is a need for an authentic experiential learning component within pre-service teacher training courses. Providing pre-service teachers with positive international educational and service-learning experiences is necessary as a prerequisite for preparing elementary school teachers who are culturally responsive, globally aware, and pedagogically competent in addressing the needs of diverse learners. To accomplish this goal, $\$$ it is important to establish school-university collaborative partnerships with a common purpose. [Goodlad, 1988: 52-55] contends that such utually beneficial linkages irtually untried, and therefore unstudied phenomenon. Interestingly, the last 20 years have witnessed the creation of successful endeavors leading to increased study of such collaborations [Allsopp, DeMarie, Alvarez-McHatton, Doone, 2006; Cozza, Mbugua, Noakes, Intoccia, Guzzi, Kelly, 2001; Lacina, Hagan, Griffith, 2006; Johnson, Brosnan, Cramer, Dove, 2000].

\section{On definition of culturally relevant pedagogy and Service-Learning}

Ladson-Billings [1995] defines culturally relevant teaching as a pedagogy that empowers students intellectually, socially, emotionally, and politically by using cultural referents to impart knowledge, skills, and attitudes. She outlines three criteria for culturally relevant pedagogy. First, an ability to develop students academically by effectively helping them to read, write, speak, compute, pose and solve higher order problems, while engaging in peer review of problem solutions. Second, a willingness to nurture and support cultural competence in both home and school cultures as a strategy for teachers to value and build on skills that students bring from the home culture. Third is the development of a sociopolitical or critical consciousness where teachers help students to recognize, critique, and change social inequities.

Although scholars observe that the term culturally relevant pedagogy is used interchangeably with several terms like culturally responsive, culturally appropriate, culturally congruent and culturally compatible, they concur that the term is used to describe effective pedagogy in culturally diverse classrooms. Consequently, the overarching purpose of culturally relevant pedagogy is to maximize learning for racially and ethnically diverse students 
with the recognition that all students, regardless of race or ethnicity, bring their culturally influenced cognition, behavior and dispositions with them to school.

Creating this awareness among pre-service teachers during their training becomes an imperative for culturally relevant pedagogy. Villegas and Lucas [2002] captures the essence of this pedagogical approach by asserting that it builds on the premise that how people are expected to go about learning may differ across cultures. In effect in order to maximize learning opportunities, teachers must gain knowledge of the cultures represented in their classrooms, then translate this knowledge into instructional practice. The graduate course taught in Kenya sought to fulfill this goal by the idea of reaching out and looking in; providing an opportunity for pre-service teachers to be immersed in experiential learning in the Kenyan cultural context that would equip them with a culturally responsive skill set to bring back to their USA classrooms.

A number of definitions of service-learning exist. The National Service Learning Clearinghouse defines Service-Learning as a teaching and learning strategy that integrates meaningful community service with instruction and reflection to enrich the learning experience, teach civic responsibility, and strengthen communities. According to

Eyler and Giles [1999], service-learning is a form of experiential education where learning occurs through a cycle of action and reflection as students work with others through a process of applying what they are learning to community problems and, at the same time, reflecting upon their experience as they seek to achieve real objectives for the community and deeper understanding and skills for themselves. In effect, experience enhances understanding which leads to more effective action.

Within the academic community, there is considerable agreement that service-learning is a multi-tiered pedagogy that can be implemented at any level of education, from preschool to graduate school [Baldwin, Buchanan and Radisil 2007]. Another definition characterizes service-learning as a union of community service and formal learning [Minor 2002]. In effect, students apply course concepts in the community and return take what is learned in the field back to class. Service-learning therefore is a type of experiential education that combines and pursues both academic achievement and community service in a seamless weave, requiring the use of effective reflection exercises. The latter creates relevance and meaning for students rather than creating a backlash and solidifying prejudices or perception of "extra work." Experiential learning is supported theoretically by constructivist principles suggesting that students have an active role in learning where authentic tasks are introduced. 
A growing body of research [Sheckley, Keeton 1997; Szente 2008] recognizes service-learning as an effective strategy to help students learn through; active participation in service experiences; structured time for reflection by thinking, discussing and writing about their service experience; opportunities to use skills and knowledge in real-life situations; learning beyond the classroom and into the community; and fostering a sense of caring for others.

Through service-learning, an ideal type of school-university partnerships can be forged. Equally important is the curricular integration of multicultural education which sees diversity in a community, and global education which sees the world as a community. This approach aims to widen students' and teachers' perspectives to the world while enhancing their awareness, understanding and appreciation of those who are different from them [Cushner, Safford, McClelland 2011; Mbugua, 2004; Merrifield, 2003].

\section{Rationale for graduate course development}

For the past four years, the author has been teaching a graduate course titled Cross-Cultural and Global Perspectives in Education on campus during Intersession (January semester). Although students have found the course content's focus on multicultural and global education thought provoking, rewarding and insightful, they have aptly expressed a concern over contextual relevance. Notwithstanding the interactive nature of the course - engaging discussions, role plays, simulations, guest speakers and pertinent readings, students have felt "confined" within the four walls of a college classroom in snowy northeast Pennsylvania and have consistently requested authentic experiential learning experiences. This perspective to experiential learning is supported theoretically by constructivist principles which suggest that students have an active role in learning where authentic tasks are introduced [Vygotsky, 1978]. The perceived benefits of experiential learning component served as an added impetus for the course development granted that the author, a U.S citizen was originally born in Kenya, already had a well established network with the Catholic University of East Africa, Nairobi which served as a physical base.

At the pedagogical level, Wasserman [2010] opines that teacher education faculties have experimented with service learning as a way of providing authentic field experiences for teacher candidates. Fortunately, the University of Scranton's 2010-2015 Strategic Plan integrates this notion seamlessly through Jesuit education, the goal of which is to prepare "men and women for others ... works of justice" [Arrupe 1999] who will, in the words of the Jesuit founder, Ignatius, "Go Set the World on Fire." Further, the Panuska Col- 
lege of Professional Studies (PCPS) where the course titled "Cross-Cultural and Global Perspectives" resides, has a commitment to a program of service learning which forms an integral part of the academic curriculum. Completion of service-learning experiences is a requirement for graduation. This gave a logical progression for the development of the course within an international context.

As a faculty member with extensive international experiences, these requests offered an avenue for the author to provide the students with meaningful and relevant hands-on and minds-on learning in an international context as "are men and women" for others. The creation of what the University of Scranton refers to as a "travel" credit-bearing course was undertaken and, after the appropriate course approval process, it was taught in Kenya during the summer of 2010 . The choice of this country was necessitated by a "nagging" concern over the stereotypes and lack of knowledge among pre-service teachers, about the African continent which they often refer to as a country instead of a continent. Additionally, pre-service teachers voiced the concern that their K-12 curriculum left paucity of knowledge about the African continent.

\section{Course Objectives}

The course had a total of 11 objectives that are aligned with the appropriate Pennsylvania Department of Education (PDE) standards and the National Council for Social Studies and National Council for Teachers of English academic standards. Some of the objectives state that pre-service teachers would:

1. Examine multiple perspectives on ways teachers and schools can prepare young people for participation in a culturally diverse society and interconnected world.

2. Identify cultural identities and investigate similarities and differences among cultures in addressing human needs and concerns such as social injustices and privilege.

3. Interpret patterns of behavior reflecting values and attitudes that contribute or pose obstacles to cross-cultural understandings by describing a critical incident.

4. Apply course concepts such as ethnicity, culture, cultural identity, race, class, gender, disability, power, prejudice, injustice, privilege, and inequality to the examination.

5. Demonstrate an understanding of intercultural communication model while interacting with people of diverse backgrounds. 
6. Demonstrate culturally competence through application of Basic Interpersonal Communication (BIC) and simple Cognitive Academic Language Proficiency [Krashen, 1982] by speaking basic Swahili language phrases while engaging in service at elementary schools.

7. Identify and evaluate instructional materials and local/global resources for cultural universals, cultural diversity and interconnections across cultures.

8. Demonstrate knowledge and skills in perspective consciousness by reading critically.

\section{Logistics of the course}

The course entailed pre, during and post reading assignments and activities. Pre immersion components entailed background information on Kenya through readings on Kenya's past and present history (Elkin's Imperial Reckoning: British Gulag in Kenya; Rodney's How Europe Underdeveloped Africa; Maathai's Unbowed; learning of the basic Swahili language although English is the official language and main medium of instruction in Kenya; and evaluating multicultural, international, and translated children's literature for cultural universals, stereotypes, and biases. To better understanding crosscultural communication and the impending international travel to Kenya, pre-service teachers analyzed a cross-cultural interaction model [Cushner 2008] to form an integrative personal knowledge prior to the departure for Kenya. The basic premise of this model is that individuals have similar reaction to cross-cultural encounters regardless of setting, person interacting with, role adopted, and cultural background. First is an emotional arousal and culture shock of unfamiliar settings. This is followed by understanding of unfamiliar behavior due to new information and integrated knowledge. Finally, there is personal adjustment and growth mediated by cross-cultural experiences.

While in Kenya, pre-service teachers interacted with teachers and students in Kenyan schools ranging from affluent suburban private schools, to city slum schools and rural government schools through observations and in one school, they engaged in a teaching experience. Banks and Banks [2009] identify these teacher/student interactions in the classroom as "actual sites" which determine the success or failure of learning based on instructional strategies as well as teacher attitude to both student diversity and content of the subject matter being taught. In this instance, pre-service teachers employed pertinent aspects of Banks and Banks' [1997] five dimensions of content integration, knowledge construction, prejudice reduction, equity peda- 
gogy, and empowering school culture. Specific to content integration, they used a wide variety of content from different geographic regions to integrate voices of other cultures. They were able to experience other aspects of Kenyan classrooms such as issues of gender, socio-economic levels, and learning styles. Pivotal in the latter was the observable remarkable quest for an education and respect for teachers among Kenyan children. In effect, this reduced the need for classroom management strategies. The course content was complemented with the service learning component which counted towards requirements for course completion. Pre-service teachers engaged in best practices through further readings, attending guest lectures at the Catholic University of East Africa to interact with the graduate peers and get a sense of college classrooms in Kenya. In order to gain a better understanding of issues of environment and sustainability, students went on a two day eco-tourism safari. Additional authentic experiences included gaining first hand information through interviewing cultural consultants on Kenya, and analyzing pertinent current events for perspective-taking.

Another aspect of course content entailed some of the culturally relevant instructional behaviors identified in the literature by Villegas and Lucas [2002]. These included; involving pre-service teachers in the construction of knowledge, learning strategies of building on students' interests and linguistic abilities, the importance of building home-school connections to tap on their resources, important ways of examining the elementary school curriculum from multiple perspectives.

As a prerequisite for the necessary conditions for service-learning while in Kenya, a variety of guidelines needed to be met. The integration of service-learning experience with classroom activities, engaging in quality reflections on service experiences, and establishing a close relationship with community members [Pinzon, Barriga 2006] was necessary. The experiential learning component allowed each student to complete two reflective assignments. The first one involved attendance of a cultural event or activity in which the student would experience "otherness" with respect to language, race, religion, gender, etc. The second task involved working in a classroom with students in a linguistically and culturally diverse setting and teaching a lesson integrating global education principles [Merrifield, Jarchow 1997; Swiniarski, Birsner, Breitborde 2002].

Bringle and Hatcher [1995] explain that such a course provides an educational experience in which students (a) participate in an organized service activity that meets identified community needs, and (b) reflect on the service activeity in such a way as to gain further understanding of curricular content, a broader appreciation of the discipline, and an enhanced sense of personal values and civic responsibility. O'Grady [2000], states that service- 
learning enhances what is taught in school and helps foster the development of a sense of caring for others. This idea aligns well with a caring teacher disposition which is one of the four critical aspects of culturally responsive teaching - caring, communication, curriculum and instruction.

Further, while in Kenya where pre-service teachers showed an ethic of care especially when working with students who were HIV/AIDs infected (carried the HIV/AIDs virus) or affected (have lost family members to HIV/AIDs) at Nyumbani Children's Home. Pre-service teachers demonstrated the ethic of care and communication while teaching in low income slum classes that had 1:65 teacher student ratio. They were able to use some Swahili phrases in the class when teaching social studies with both Kenyan and USA children's books. Their instruction was altered through This high ratio was necessitated by the 2002 provision of free primary education in Kenya an effort to meet the UN Millennium Goals and Education For All.

Upon return to the United States, pre-service teachers completed their final assignment. This involved the completion of a e-journal entry detailing their experiences and making meaningful connections to course content.

\section{Benefits of international service-learning experiences for culturally responsive teaching}

Preliminary e-journal entries by pre-service teachers were analyzed using a model developed by Harwood, Fliss, and Gaudling [2006]. This model comprises six categories along which students completed journal entries: a) understanding service-learning pedagogy - students indicated that they felt in "solidarity" with the community and benefited from helping, b) understanding the community - the application of course concepts, use of pertinent instructional resources and multicultural as well as Kenyan children's literature in real Kenyan classrooms elucidated the different socio-economic experiences students in Kenya and cross-cultural interactions, c) understanding of students - the intercultural communication model of using BICS coupled with normal child development theories was useful especially in the lower grades where children were taught in a two or three languages, d) general pedagogical understanding - the importance of differentiating instruction for diverse learners was an imperative, as well as using culturally appropriate materials and communication e) knowledge about self - the international experiences resulted in "self-discovery" and a keen ability to listen and learn as well as an understanding of personally privileged position in society [Sleeter 2000], and f) general commentary on the impact of the practicum experience - students observed that it was the most transformative experience of their 
lives that equipped them with the knowledge and skills to be culturally competent through first hand experiences with the "other." They found this to be a powerful experiential learning opportunity that would enable them to be culturally sensitive and responsive teachers in the USA. More specifically, pre-service teachers reported that the experiences were beneficial to their professional development as they gained a sense of empathy for minority students who they may work with in the USA. This sense of empathy was developed after first hand experiences of being in the minority position while in various Kenyan settings such as churches, schools, or community events.

The key notion is that teachers and students need to be involved in civic engagement - exercising their ethical and civic duty by while meeting community needs, The result is that all participants learn from one another and experience personal transformation and gratification - university students providing service benefited as much, if not more, as those for whom service is rendered. Examples of such projects in Kenya involved cleaning classrooms, organizing resources for each classroom, and helping with tutoring and after-school programs.

\section{Challenges of international service-learning experiences for culturally responsive teaching}

There was a low number of students taking the course which may be translated as being counter-productive in terms of the intended benefits of preparing culturally relevant pedagogy among pre-service teachers and their future elementary school students. Merrifield [2003] corroborates this observation by stating that a number of factors contribute to low participation by education students in such international credit bearing courses. Among these factors is a crowded curriculum, an apparent lack of overseas programs that are creditable for education majors, financial aid, and advisors with undeveloped appreciation for the benefits of experiencing other cultures. An illustrative example of the former is Pennsylvania Department of Education's reform agenda on new certification revisions referred to as Chapter 49 [PDE 2008]. The effect of this educational reform in Pennsylvania is the increase in the number of competency-based courses and field hours that education students must complete in the field prior to certification. This crowded curriculum has necessitated the designation of the course as an elective than required.

Preparing such a course requires an inordinate amount of time for planning and implementation often without institutional financial support. Even with a strong belief and passion for providing students with opportunities for 
culturally responsive teaching skills, and international service-learning experiences that connect theory and practice through hands-on field-based activities, the logistical issues of course development and implementation are time consuming and exhausting.

\section{Conclusions}

This international service-learning course offered opportunities for internationalizing teacher training [Schneider 2003] and unique possibilities for enhancing academic achievement and professional development [Annette 2003; Roberts 2003; Grusky 2000]. Preliminary tangible outcomes of this service-learning experience in Kenya included enhanced critical thinking skills and culturally relevant pedagogy. There was greater appreciation of cultural diversity, awareness of global issues, expanded notions of local and global communities, and the acquisition of general cross-cultural competencies [Lewis, Niesenbaum 2005; Van Hoff, Verbeeten 2005; Kiely 2005; Annette 2003; Thompson 2002]. Another unique outcome was what Wade, Boyle-Baise, and O 'Grady (2001) refers to as experiences that may expand the "comfort zone" of participant teachers while enhancing their abilities to view the world from multiple perspectives. In addition, international service-learning experiences may lead to enhanced personal and professional flexibility [Roberts, 2003]. It is often argued that international service-learning programs are potentially transformative in nature [Kiely 2005; Roberts 2003; Grusky 2000]. International service-learning component of the course allowed for the emergence of collaborative partnership that benefited all concerned pre-service teachers, students and teachers in Kenyan primary schools children, and the local and global communities. The opportunity enabled pre-service teachers to meet Pinzon and Barriga [2006] criteria for integrating course content with field experiences, engaging in reflection, and building relationships with the community. An added dimension of learning took place through action and reflection rather than from simply from reading and lectures [Eyler, Giles 1999].

\section{References}

Allsopp, D. H., DeMarie, D., AlvarezMcHatton, R., Doone, E. 2006. Bridging the gap between theory and practice: Connecting courses with field experiences. In Teacher Education Quarterly, 33 (1): 19 - 35.

Annette, J. 2003. Service-learning internationally: Developing a global civil society. In S. H. Billig, J. Eyler (eds.). Deconstructing service-learning: Research exploring context, participation, and impacts. Greenwich, CT: Information Age Publishing, 241-249. 
Arrupe, P. 1999. Men and women for others. In J.J. Callahan (ed.). In First principles: The Jesuit tradition in higher education. Kansas City, MO: J. J. Callahan, 10 - 12.

Baldwin, S. C, Buchanan, A. M., Rudisill, M. E. 2007. What teacher candidates learned about diversity, social justice, and themselves from service-learning experiences. In Journal of Teacher Education, 58 (4): 315 - 327.

Banks, J., Banks, C. (eds). 2009. Multicultural Education: Issues and Perspectives ( $7^{\text {th }}$ ed.). NJ: Wiley, Sons, Inc.

Cozza, B, Mbugua, T., Noakes, P., Intoccia, M., Guzzi, L., Kelly, M. 2001. Family/ School/university collaboration to enrich social studies instruction. In M. Christenson, M. Johnson \& J. Norris (eds.). Family/school/university collaboration to improve social studies education. Silver Spring, MD: National Council for Social Studies, $39-48$.

Cushner, K., Safford, P. McClelland, A. 2008. Human Diversity in Education: An Integrative Approach. Columbus, OH: McGraw-Hill College.

Eyler, J., Giles, J. 1999. Where's the Learning in Service-Learning? San Francisco: Jossey-Bass.

Ference, R. A., Bell, S. 2004. A cross-cultural immersion in the U.S.: Changing preservice teacher attitudes toward Latino ESOL students. In Equity \& Excellence in Education, 37 (4): 343 - 350.

Goodlad, J. 1988. School-university partnerships for educational renewal: Rationale and concepts. In Sorotnik, K. A., Goodlad, J. I. (eds.). School-university partnerships in action: Concepts, cases, and concerns. New York: Teachers College Press, 3 - 31 .

Grusky, S. 2000. International service learning. In American Behavioral Scientist, 43 (5): $858-868$.

Johnson, M., Brosnan, P., Cramer, D.,Dove, T. (eds.). 2000. Collaborative Reform and Other Improbable Dreams: The Challenges of Professional Development Schools. Albany, NY: State University. New York Press.

Kiely, R. 2005. Transformative international service-learning. In Academic Exchange Guarterly, 9 (1): $275-281$.

Krashen, S. 1982. Principles and practices of second language acquisition. Oxford: Pergamon Press.

Lacina, J., Hagan, L., Griffith, B. 2006. Developing a writing workshop classroom: Collaboration between a charter school principal, second-grade teacher, and university professor. In The Teacher Educator, 42(1): 63 - 75.

Mbugua, T. 2004. Authentic Learning: Intercultural, International, and Intergenerational Experiences in Elementary Classrooms. In Childhood Education, 80 (5): 237 245.

Merrifield, M., Jarchow, S. 1997. Preparing Teachers to Teach Global Perspectives. Thousand Oaks, CA: Corwin Press.

Merrifield, M., Jarchow, S. 2003. The State of Teacher Training for K-12 International Education. In Conference on Global Challenges and U.S. Higher Education: National Needs and Policy Implications. Duke University: Durham, NC. 
Minor, J. 2002. Incorporating service learning into ESL programs. In TESOL Journal, 22 (4), $10-14$.

PDE, Pennsylvania Department of Education. 2008. A framework for new certification guidelines: Pre-k 4. Harrisburg, PA: Retrieved November 20, 2010 from [http:// www.pde.state.pa.us/chapter49/cwp/view.asp]

Pinzon, D., Barriga, F. 2006. Critical thinking in a higher education service-learning program. In K.M. Casey, G. Davidson, S. H. Billig, \& N. C. Springer (eds.). Advancing knowledge in service-learning: Research to transform the field. Greenwich, CT: IAP, $89-110$.

Sheckley, B., Keeton, M. 1997. Service-Learning: A theoretical model. In J. Schine (eds.), Service-Learning: Ninety-sixth Yearbook of the National Society for the study of education. Chicago: The University of Chicago Press, 32 - 55.

Sleeter, C. 2000. Multicultural education, social positionality, and whiteness. In E. Duarte, S. Smith (eds.). Foundational perspectives in multicultural education. New York: McGraw Hill, 118 - 143.

Swiniarski, Birsner, E. Breitborde, M. 2002. Educating the Global Village: Including The Child In The World. NY: Prentice Hall.

Szente, J. 2008. Preparing pre-service teachers to work with culturally and linguistically diverse children: A service-learning experience. In Journal of Early Childhood Teacher Education, 29 (2), 140 - 145.

University of Scranton, 2010. Strategic Plan 2010 - 2015. Retrieved November 23, 2010, [http://matrix.scranton.edu/pir/strategic-plan/index.shtml].

Van Hoof, H. B.,Verheeren, M. J. 2005. Wine is for drinking, water is for washing: Student opinions about international exchange programs. In Journal of Studies in International Education, 9 (1), 42 - 61.

Villegas, Lucas, 2002. Educating Culturally Responsive Teachers: A Coherent Approach. New York: State University of New York Press.

Wade, R. C, Boyle-Baise, M., O'Grady, C. 2001. Multicultural service learning in Teacher education. In J. B. Anderson, K. J. Swick, J. Yff (eds.). Servicelearning in teacher education. Washington, DC: AACTE Publications, 248 - 259.

Vygotsky, L. S. 1978. Mind and society: The development of higher mental processes. Cambridge, MA: Harvard University Press.

\section{Author}

Tata Mbugua, Ph.D., Associate Professor

University of Scranton

Department of Education

MGH 145

Scranton, PA 18510

USA

E-mail: mbuguat2@scranton.edu 